\title{
A Case of Blue Nevus of Posterior Wall of Pharynx
}

\author{
Jun Young Lee, Sun Wook Kim, Hyo Geun Choi, and Bum Jung Park \\ Department of Otorhinolaryngology-Head and Neck Surgery, Hallym University College of Medicine, Anyang, Korea
}

\author{
인두 후벽에 발생한 청색 모반 환자 1예 \\ 이준영 · 김선욱 · 최효근 · 박범정 \\ 한림대학교 의과대학 이비인후-두경부외과학교실
}

\author{
Received August 14, 2019 \\ Revised October 13, 2019 \\ Accepted November 4, 2019 \\ Address for correspondence \\ Bum Jung Park, MD, PhD \\ Department of Otorhinolaryngology- \\ Head and Neck Surgery, \\ Hallym University \\ Sacred Heart Hospital, \\ 22 Gwanpyeong-ro 170beon-gil, \\ Dongan-gu, Anyang 14068, Korea \\ Tel $+82-31-380-3840$ \\ Fax $+82-31-386-3860$ \\ E-mail pbj426@hallym.or.kr
}

\begin{abstract}
Menalocytic nevi are benign localized pigmented lesions, which usually occur on the cutaneous surface of the body but rarely on the mucous membranes. It is comparatively easy to encounter pigmented lesions of the oral cavity, but the melanocytic nevi of the pharyngeal wall are extremely rare worldwide and, to the best of our knowledge, there is no reported case of melanocytic nevus arising from pharyngeal wall. We report a case of a pigmented lesion on the posterior wall of pharynx, which was microscopically confirmed as oropharyngeal blue nevus.
\end{abstract} Korean J Otorhinolaryngol-Head Neck Surg 2020;63(4):180-2

Key Words Melanoma $\cdot$ Nevus, blue $\cdot$ Pharynx.

\section{서 론}

색소모반은 피부 혹은 점막의 멜라닌세포 증식을 동반하 는 양성 병변을 뜻하며, 흔히 무증상의 독립적으로 생성된 검 푸른 색상 변화를 동반한 매끈한 표면의 형태로 나타난다.) 색소모반의 경우 대개 체외 피부표면에 나타나며 구강, 소화 기계, 호흡기계 점막에서는 드물게 나타난다.2) 점막과 피부에 서 나타나는 모반성 색소병변의 빈도 차이에 대한 정확한 병 태생리학적인 이유는 밝혀진 바는 없지만, 표피, 진피, 피하층 으로 나뉘어진 피부층과는 달리 구강 및 인두 점막은 점막, 점막하로 나뉘어져 표피의 생리가 다르고, 인두 및 구강점막 의 멜라닌 세포의 역할은 피부의 멜라닌세포와 역할이 다르 다고 추정된다는 점, ${ }^{3}$ 또한 피부에 비해 자외선 등의 위험인 자에 극도로 낮은 빈도로 노출되며 실제로 육안상 관찰되는 빈도에서 훨씬 더 낮은 빈도를 보인다는 점 등으로 추정할 수

This is an Open Access article distributed under the terms of the Creative Commons Attribution Non-Commercial License (https://creativecommons.org/licenses/by-nc/4.0) which permits unrestricted non-commercial use, distribution, and reproduction in any medium, provided the original work is properly cited.
있다. 색소 병변을 주소로 내원하는 이비인후과 환자의 대부 분이 구강내 병변의 형태로 나타나며, 인두 및 그 외의 위치 에는 굉장히 드물게 나타난다. 따라서 인두점막의 착색 병변 으로 병원을 내원하는 경우 진균 등의 감염질환이나 외인적 인자에 의해 발생한 질환으로 오인이 가능하며 악성 흑색종 등의 예후가 불량한 병변의 경우 조직학적 진단 및 치료가 늦어질 경우 치명적인 결과를 초래할 수 있어 구강 혹은 구 인두의 착색 병변을 주소로 내원한 환자에 대해서는 정밀한 신체진찰과 문진 및 정확한 조기 진단과 치료를 요한다.

저자는 국내에서는 보고된 바가 없는 인두 후벽에 발생한 청색모반 환자 1 예에 대해 경험하였기에 문헌 고찰을 통해 보 고하여, 차후 인두 등의 착색병변을 주소로 내원한 환자들의 진단 및 치료에 도움이 되고자 한다.

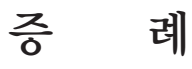

35세 여자환자가 우연히 발견된 구인강 후벽의 흑색 병변 을 주소로 내원하였다. 환자는 목안의 불편감, 호흡곤란 등의 
특이 병력이 전혀 없었으며 그 외 이비인후과적 증상은 없는 상태였다. 환자 과거력상 흡연력, 외상력, 감염력 등은 전무하 였으며 신체진찰상 피부 및 점막의 색상변화를 동반하는 병 변은 없었다. 기저질환은 타원에서 시행한 갑상선초음파상 결절이 보인다는 소견 외에는 없었다. 환자는 타원 여러 곳에 서 진료를 보았으나, 특별한 진단 없이 본원을 내원하였으며, 타원에서 진균 감염 의증하 약물적 치료 시행했으나 병변의 변화 보이지 않아 본원으로 내원하였다. 본원 내원 당시 시행 한 후두내시경 소견상 구인강 및 비인강 후벽이 전반적으로 검푸른색으로 착색된 병변이 침착되어 있는 소견을 볼 수 있 었다(Fig. 1). 병변은 비인강 후벽부터 구인강 하부까지 전반 적으로 퍼져있는 소견을 보였다. 비인강 및 구인강의 후벽 외 에는 구강 내 특이소견은 보이지 않았다.

환자에 대한 초치료로 우선 경험적인 항진균제 사용 및 $50 \mathrm{cc}$ 시린지를 사용한 비인강 세척을 시행하고, 2주 뒤 추가적인 혈액학적 검사 및 경부 전산화단층촬영과 함께 외래 추적관 찰을 시행하였다. 환자의 혈액학적인 소견상 이상소견은 보이 지 않았으며, 전산화단층소견에서도 인두 후벽에 영상의학적 이상 병변은 보이지 않았다. 2주간의 치료에도 불구하고, 환 자 인두 후벽의 병변에 변화를 보이지 않았으며, 이에 내시경 하 조직생검을 계획하였다.

인두 후벽의 착색된 병변을 내시경을 통해 접근하여 국소 마취 후 일부 채취하였으며 조직검사를 시행하였다. 채취한 조직의 병리학적 소견상 착색된 멜라닌 포식구들의 침윤과 점막 조직이 관찰되었으며(Fig. 2), 병리학적 소견상 청색 모 반으로 결론 지을 수 있었다.

조직 검사 후 환자에 대한 특별한 치료는 시행하지 않았으 며, 정기적인 외래 추적관찰을 시행하기로 하였다. 이후 환자 의 병변에서는 특이할 만한 변화는 보이지 않았다.

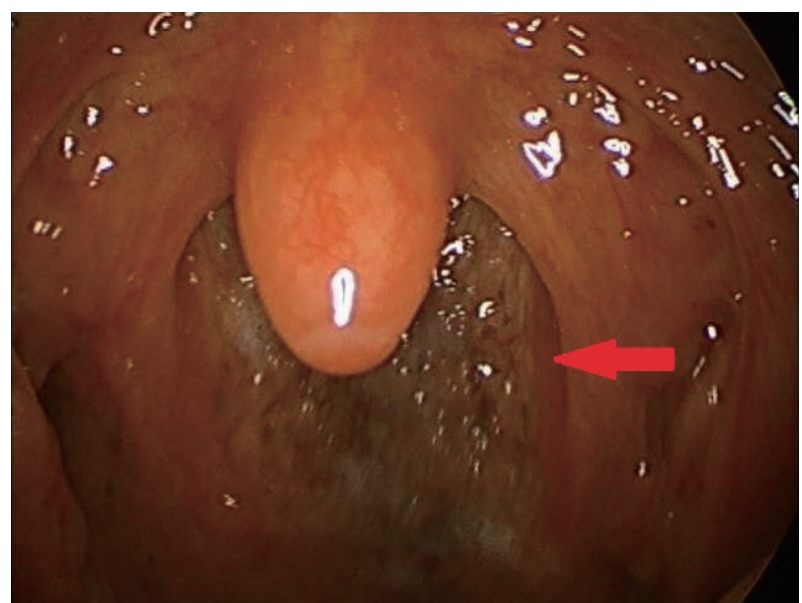

Fig. 1. Endoscopic examination revealed a dark pigmented pharyngeal mucosa extending over the posterior pharyngeal wall (arrow).

\section{고 찰}

구강 내 발생한 색소병변의 진단을 위해서는 먼저 외인적 인자에 의한 착색을 확인하기 위한 약물 복용력, 아말감 등 의 착색을 유발할 요인에 대한 과거력 확인이 필요하다. 그 외 구강의 착색을 동반할 수 있는 전신 질환에 대한 감별이 필요하다. ${ }^{4}$ 구강점막에 생기는 색소모반 중에는 점막내 모반 이 가장 흔하며(63\%), 그 다음으로 청색 모반(19\%), 복합 모 반(9\%) 등이 그 다음으로 흔하게 발생한다. ${ }^{5)}$

청색 모반은 통상적으로 피부에 발생하나 종종 점막에서 도 발견되기도 하는 양성의 착색된 국소 병변이다. 일반적으 로는 상하지의 배부, 두피, 엉덩이 등의 피부 표면에 발생하며, 점막에 발생하는 경우 구강 및 비강내 점막 혹은 여성 생식 기 등에도 발생한다고 보고된 바 있다. ${ }^{6-8)}$ 조직학적으로는 피 부 표면이 아닌 망상층 등에 깊숙이 위치한 착색된 방추세포 및 멜라닌포식구, 그리고 멜라닌세포 등의 군집들을 보이게 되 며, 대부분의 모반과는 달리 특징적으로 진피층에 멜라닌 세 포가 침윤해 있으며, 섬유아세포 및 교원섬유가 진피층에 증 가해 있다. 피부표피층이 아닌 진피층에 위치한 색소로 인해 짧은 파장의 가시광선은 흩어져 버리는 이른바, Tyndall 효과 로 인해 육안으로는 푸른색 혹은 검푸른색으로 관찰된다. ${ }^{9}$

인두 내 청색모반과의 감별을 요하는 질환으로는 구강내 발생하는 흑색종, 가성흑색종, 약물 유발성 착색병변, 치아 아말감에 의한 착색병변 등이 있다. ${ }^{10)}$ 이들 중 가장 임상적 감 별을 요하는 질환은 원격전이가 흔하고 예후가 불량한 점막 흑색종이다. 점막 흑색종의 경우 궤양, 출혈 등을 동반하는 경우가 많고 구강 내 불규칙한 모양의 돌출된 종괴의 형태로 나타나는 점에서 육안상 타 색소병변 질환과 차이를 보이나 구인두의 점막흑색종의 경우 그 증례가 드물어 임상양상에

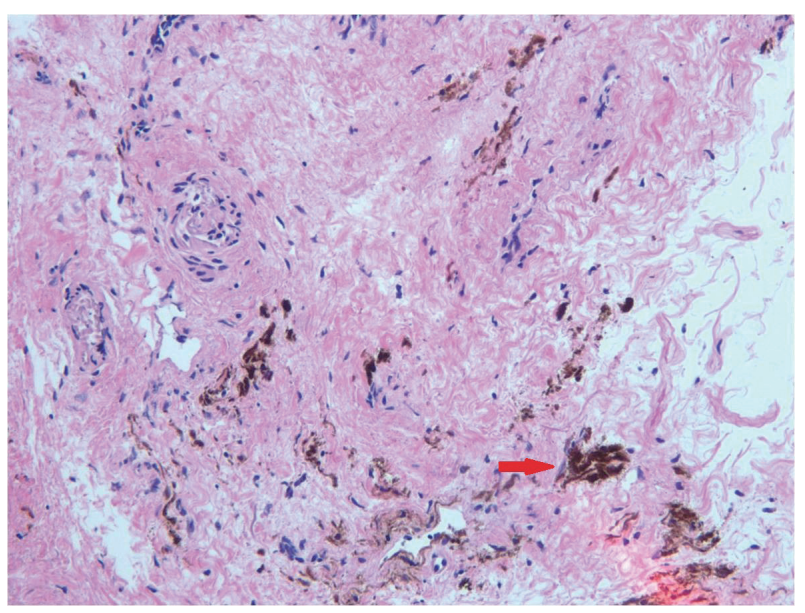

Fig. 2. Histopathologic finding of oropharyngeal blue cell nevus. A clutstered melanocytes (arrow) are noted among the dense collagenous fibers (H\&E stain, $\times 400)$. 
대해 알려진바 많지 않고 치료가 어려우며 예후가 불량하여 반드시 조직학적 생검을 통한 확진을 요한다. ${ }^{11)}$ 흑색종의 경 우 조직학적 소견상 세포의 불규칙한 다형성, 세포 분열의 활 성화, 점막 고유층의 침윤 등의 특징을 가지나 본 증례의 경 우 망상 진피 내에 국한된 비교적 균질한 형태를 가진 방추 형의 멜라닌세포 및 멜라닌탐식세포 외에는 특이 소견은 보 이지 않아, 점막 흑색종은 우선적으로 배제할 수 있었다.

또한 청색모반의 경우 병변의 색상이 청색을 나타내어 여 러 형태의 혈관종과의 감별을 요하며, ${ }^{10)}$ 따라서 해당 병변에 대한 펀치 생검 등의 조직학적 생검을 계획하기 전 영상학적 검사를 통한 병변의 범위와 출혈 가능성을 판단하는 것이 중 요할 것으로 생각된다. 본 증례의 경우 구인두암 및 혈관종 등 과의 감별을 위해 시행한 전산화단층촬영에서 구인두 후벽 에는 조영 증강되는 병변 등은 관찰되지 않았으며, 그 외 특 이소견은 보이지 않아 특별한 전 처치 없이 내시경하 조직 생 검을 시행하였다.

현재까지 구강 및 구인두의 청색모반이 악성 흑색종 등의 악성 변화를 보인 증례는 보고된 바가 없으며 그 증례가 매 우 드물어 그 병변의 악성 변화도 및 예후에 대해서는 알려져 있지 않다. 다만 George 등르는 병변 일부에서 채취한 검체는 청색 모반의 병리학적 형태를 띄나 일부는 국소 전이를 동반 한 악성 흑색종의 병변을 띄는 두피에 발생한 악성 흑색종의 증례를 보고 하였다. 이는 단순히 육안상 청색 모반이라 생 각되더라도 병변 전체에 대한 병리학적 검사가 면밀히 필요 함을 시사하며, Lai 등 ${ }^{10)}$ 은 악성 흑색종 등과의 감별 및 모반 의 악성 전조 병변 가능성을 고려하여 수술적 절제가 가능하 다면 가능한 모든 병변의 절제 및 해당 병변의 제거를 통한 치료 및 조직의 병리학적 생검을 권고하였다.

본 증례의 경우 비인두 및 구인두에 이어지는 광범위한 착 색 병변으로써 병변의 위치와 크기를 고려하였을 때 수술적 완전 절제는 불가능하여 병변 여러 부위에서 시행한 조직학 적 검사를 통한 확진 후 경과관찰 하였다. 구강 및 구인두의 광범위한 색소 병변의 경우 현재 보고된 대부분의 증례에서 는 검체의 일부를 채취하여 조직학적 진단 후 양성 종양임이 확인 될 경우 경과관찰 하였다. ${ }^{10,11,13)}$ Santos 등 ${ }^{14)}$ 이 발표한 증 례와 같이 구강 및 인두에 발생한 $5 \mathrm{~cm}$ 이상의 광범위한 청 색 모반에 대한 광범위 전절제술을 시행한 증례가 보고되어 있긴 하지만, 이는 환자가 오랜 흡연자로 추후 병변의 악성 변 화도가 높을 것으로 생각하였으며, 치료 순응도가 떨어져 정 기적인 외래 추적관찰이 불가하였던 점을 고려하여 시행한 결정이었다.

결과적으로 구인두의 어두운 착색 병변이 관찰되었을 경 우 우선적으로 수술적 완전한 절제가 권고되고 해부학적 위
치 및 범위로 인해 완전한 절제가 불가능하더라도 인두에 생 기는 구강점막의 착색 병변이 매우 희귀함을 고려하였을 때 점막 흑색종 등과의 감별 및 모반의 악성 전조 병변 가능성 을 감별해야 하므로, 병변 여러 부위에서의 생검을 통한 조직 학적 확진을 하는 것이 중요하다고 생각된다. 특히나 병변의 색상이나 크기의 변화가 있을 시에는 반드시 조직학적 생검 이 필요할 것으로 생각된다.

\section{Acknowledgments}

None.

\section{Author Contribution}

Conceptualization: Hyo Geun Choi. Data curation: Jun Young Lee. Formal analysis: Jun Young Lee. Funding acquisition: Jun Young Lee. Investigation: Jun Young Lee. Methodology: Jun Young Lee. Project administration: Jun Young Lee. Resources: Sun Wook Kim. Software: Jun Young Lee. Supervision: Jun Young Lee. Validation: Sun Wook Kim. Visualization: Sun Wook Kim. Writing —original draft: Jun Young Lee. Writing_-review \& editing: Bum Jung Park.

\section{ORCID}

Bum Jung Park https://orcid.org/0000-0001-6074-6339

\section{REFERENCES}

1) Scofield HH. The blue (Jadassohn-Tièche) nevus: A previously unreported intraoral lesion. J Oral Surg Anesth Hosp Dent Serv 1959;17(1):4-14.

2) Scotto J, Fraumeni JF Jr, Lee JA. Melanomas of the eye and other noncutaneous sites: Epidemiologic aspects. J Natl Cancer Inst 1976; 56(3):489-91.

3) Barrett AW, Scully C. Human oral mucosal melanocytes: A review. J Oral Pathol Med 1994;23(3):97-103.

4) Lenane P, Powell FC. Oral pigmentation. J Eur Acad Dermatol Venereol 2000;14(6):448-65.

5) Buchner A, Hansen LS. Pigmented nevi of the oral mucosa: A clinicopathologic study of 32 new cases and review of 75 cases from the literature. Part I. A clinicopathologic study of 32 new cases. Oral Surg Oral Med Oral Pathol 1979;48(2):131-42.

6) Buchner A, Leider AS, Merrell PW, Carpenter WM. Melanocytic nevi of the oral mucosa: A clinicopathologic study of 130 cases from northern California. J Oral Pathol Med 1990;19(5):197-201.

7) Jiji V. Blue nevus of the endocervix. Review of the literature. Arch Pathol 1971;92(3):203-5.

8) Makker J, Sakam S, Arety P, Niazi M, Balar B. Rectal blue nevus: Case report of a rare entity and literature review. Pathol Res Pract 2015;211(8):625-7.

9) Zembowicz A, Mihm MC. Dermal dendritic melanocytic proliferations: An update. Histopathology 2004;45(5):433-51.

10) Lai WS, Hsu CH, Lee JC, Chu YH. Extensive blue nevus of the pharynx. Indian J Dermatol Venereol Leprol 2012;78(3):376-7.

11) Saito C, Ishikawa K, Nakamura K, Fujita A, Shimizu M, Fukushima $\mathrm{N}$, et al. A melanocytic lesion extending from the right ear to the nasopharynx in a pediatric patient: A case report. Ann Otol Rhinol Laryngol 2015;124(8):609-13.

12) George SJ, Green P, Walsh NM. Unusual melanoma of the scalp with blue nevus-like features and local metastasis: A case report. SAGE Open Med Case Rep 2019;7:1-5.

13) Lee JS, Do JE, Kim YC. A case of congenital common blue nevus of the upper lip. Korean J Dermatol 2007;45(1):40-2.

14) Santos Tde S, Frota R, Martins-Filho PR, Cavalcante JR, Raimundo Rde C, Andrade ES. Extensive intraoral blue nevus--case report. An Bras Dermatol 2011;86(4 Suppl 1):S61-5. 